VALESCA LIMA \& SUE A. S. IAMAMOTO'

\title{
"Culture War" against Brazilian universities: how budget cuts and changes in tertiary education policies are affecting the academic community ${ }^{2}$
}

After the 2018 presidential election that was filled with political tensions and aggressions, Jair Bolsonaro began his administration focusing on new laws that would allegedly 'reduce' criminality and 'fix' the economy. Soon, however, he announced his intention to pursue a campaign promising to eliminate "cultural Marxism" from Brazilian public universities. "Cultural Marxism", also described as the "culture war", is an integral part of the conspiracy theories of the contemporary right against progressive ideas. As a distorted allusion to Gramsci's theory of hegemony and competing political views, the campaign against "Cultural Marxism" has ended up endorsing the persecution of the (perceived) leftist indoctrination of schools and universities.

The declared war against the tertiary education sector in Brazil comes together with severe budget cuts to the federal education system, increasing the threats to academic freedoms and episodes of violence targeting students and academic staff and a scheme to open public universities to private sector investment and management. These cuts are part of broader neoliberal policies that directly attack social rights by transforming them into commodities. In the case of Brazil, these policies not only undermine a public, high-quality and free higher education system, guaranteed by the 1988 Federal Constitution, but also public-oriented scientific research, funded by the federal government.

\footnotetext{
'VALESCA LIMA is postdoctoral research fellow at Maynooth University specialising in governance, housing policies and social movements. SUE IAMAMOTO is a researcher in the Department of Political Science, at Federal University of Bahia.

2 This article was originally published in: http://www.alternautas.net/blog/2020/9/9/culture-waragainst-brazilian-universities-how-budget-cuts-and-changes-in-tertiary-education-policies-areaffecting-the-academic-community
} 
In this article, we discuss the assaults on Brazil's higher education system, the significant pressure on the autonomy of public universities, the limitation of funding for specific disciplines, the consequences of the current policies for the internationalisation of Brazilian universities, and the threats to local science and innovation that have caused concern for scholars and students.

\section{Quality of Brazilian Universities}

In a speech during at a public event in December 2019, President Bolsonaro criticized Brazilian public universities, saying that students do "everything but study" adding that there no Brazilian university among the 200 best in the world. His criticism was directed to public universities, considered inefficient and "ideological" by his government. However, government criticism against Brazilian higher education productivity is unsubstantiated. Even if one considers ranking systems a valid measure of educational standards, when compared to its neighbours, Brazilian universities dominate the list of best universities in Latin America and hold six of the top ten places in 2018, according to Times Higher Education's World University Rankings. ${ }^{3}$

Brazilian universities have contributed to the advance of knowledge across the country and are favourably recognised abroad despite the structural lack of funding for education. ${ }^{4}$ According to the report "Research in Brazil", commissioned by the Coordination for the Improvement of Higher Education Personnel (CAPES), a major research funding agency, Brazil is the 13th largest producer of research publications internationally and the country's citation impact has increased by $15 \%$ between 2011 to 2016. Research produced by Brazilian scholars has also had impacts outside academia. In one example, an innovative Tilapia fish skin dressing was developed by the Federal University of Ceará to help with the reconstruction of

3 Times Higher Education, 2019. Best universities in Latin America 2019 [WWW Document]. Times Higher Education (THE). URL https://www.timeshighereducation.com/student/bestuniversities/best-universities-latin-america (accessed 2.7.20).

4 Suzigan, W., Albuquerque, E. da M., 2011. The underestimated role of universities for the Brazilian system of innovation. Brazilian Journal of Political Economy 31, 3-30. 


\section{"Culture War" against Brazilian universities | 10}

human skin when it has been burnt. This innovation has been successful across the world and has even been sent to be tested in space by NASA. ${ }^{5}$

In fact, Bolsonaro's agenda aims at privatizing public universities (through projects like Future-se, as we will explain below) and increasing the private education sector. Therefore, we should compare the quality of Brazilian public and private universities. According to the latest governmental assessment, $68 \%$ of the public universities have the highest grades ( 4 and 5), while only $18 \%$ of the private sector reached the same threshold. ${ }^{6}$

The private sector concentrates $75 \%$ of the higher education enrolment, while the public sector has only $25 \%$ (INEP, 2019). This disparity is due to a large increase of private universities in the last decades, which made cheap and low-quality undergraduate courses profitable. The process of enlargement of the private sector started in the administrations of Lula da Silva and Dilma Rousseff (both from the Workers' Party, PT), which subsidised private higher education through the expansion of student loans (Student Finance Fund, FIES) and offered tax incentives in exchange for scholarships to students from low incomes (University Programme for All, ProUni). ${ }^{7}$

In PT administrations, these policies were combined with a relative expansion of federal higher education institutions. Often considered "ivory towers", public universities have become more inclusive in recent years as a result of previous PT affirmative action policies that successfully addressed underrepresentation of students enrolled from low income, black and indigenous populations. ${ }^{8}$ While these students showed the same or better performance than other students ${ }^{9}$ and the educational

\footnotetext{
5 Tosi, M., 2019. Pesquisadores cearenses participam de equipe internacional para cirurgia com pele de tilápia. O Povo.

${ }^{6}$ Época, 2019. Sete a cada dez universidades federais têm notas máximas em índice de qualidade do MEC. Época.

7 Macedo, R.G.M., 2019. Políticas educacionais e a questão do acesso ao ensino superior: notas sobre a deseducação. Cadernos de Campo (São Paulo 1991) 28, 26-31; Costa, H.B. da, 2019. Estudantes do Prouni na crise do lulismo. Plural 26, 289-311.

8 Vieira, R.S., Arends-Kuenning, M., 2019. Affirmative action in Brazilian universities: Effects on the enrollment of targeted groups. Economics of Education Review 73, 101931.

9 Valente, R.R., Berry, B.J.L., 2017. Performance of Students Admitted through Affirmative Action in Brazil. Latin American Research Review 52, 18-34. **
} 
standards of public institutions were maintained, these policies had an effect on the demography of the public universities. For the first time, many poor and black families saw their children reaching higher education. Nevertheless, already under the Rousseff and Temer administrations, between 2015 and 2018, public universities suffered from severe cuts in their funding. ${ }^{10}$

It is against these same public universities (which were still in the process of expanding inclusion while limited by harsh financial constraints) that Bolsonaro's administration focused its criticisms. While budget restrictions were already happening before, Bolsonaro presented an orchestrated attack against these universities, combining increasing cuts with ideological persecution, the restriction of the universities' autonomy and a series of legislative initiatives that intend at privatizing the activities of these universities, as will be explained below.

\section{Bolsonaro's assault on the freedom of thought and autonomy of public universities}

Despite those and many other achievements, the current government views public universities as key strongholds for the political left and has been attacking universities to justify the government's contingency budget plans. In April, Bolsonaro proposed withdrawing funding for humanities and social science faculties, stating that the government would fund only subjects that would generate an "immediate return to taxpayers." 11 Minister of Education Abraham Weintraub also threatened to withdraw funding from three federal universities, accusing them of creating disorder (balbúrdia) and not focusing on academic performance, despite evidence to the contrary. ${ }^{12}$ Whilst neither of these policies were permitted by the Brazilian

\footnotetext{
10 Vieira, V., 2015. Governo corta 47\% dos investimentos previstos para as federais - Educação Estadão. $\bigcirc$ Estado de São Paulo.

"Bolsonaro on Twitter. 2019. "O Ministro da Educação @abrahamWeinT estuda descentralizar investimento em faculdades de filosofia e sociologia (humanas). Twitter. URL https://twitter.com/jairbolsonaro/status/1121713534402990081 (accessed 1.18.20).

${ }_{12}$ Mano, M. K.; Possas, M.; Azize, R. L.; lamamoto, S. A. S. , 2019. Ataque do governo às universidades federais é tristemente ideológico. Blog do Sakamoto. https://blogdosakamoto.blogosfera.uol.com.br/2019/05/o1/ataque-do-governo-asuniversidades-federais-e-tristemente-ideologico/ (accessed 1.18.20). 
constitution, they served to create an environment of insecurity and continuous threat to academic freedom. This was noted by the Scholars At Risk "Free to Think" 2019 Annual Report, which documented the negative impact of violence and coercion restricting inquiry and freedom of expression in Brazilian universities. ${ }^{13}$ It was the first time Brazil had appeared in the report.

In May 2019, the Ministry of Education withheld $\mathrm{R} \$ 5.8$ billion for education, using austerity as a justification. These cuts affected all federal universities equally and since the wages and pensions of civil servants were legally protected, they had a direct effect on the daily operational costs of universities. Electricity and water service bills, contracts with outsourced workers (such as cleaners and security guards), and materials such as stationery and laboratory could not be paid. Many universities threatened to close their teaching and research facilities. Brazilian civil society responded to these cuts with massive protests and tens of thousands people turned out on the streets to in defense of public education. ${ }^{14}$

More than just a political ideology that is hostile to any form of critical pedagogy in particular the work educator Paulo Freire, author of the famous book "Pedagogy of the Oppressed", Bolsonaro's administration defends profit-maximisation models and privatisation of public universities. After suspending the budget, the government launched the programme "Future-se", a legislative bill designed to increase the "financial autonomy" of public universities, to enhance their relationship with the private sector and relieve the government of their funding. One of the main features of the bill is to create an endowment fund with the participation of the private sector to support teaching and research activities. The universities that participate in the programme would be able to access this fund, besides receiving additional funding from the Ministry of Education and scholarships from CAPES. In exchange, the universities would have to abide by productivity targets and key performance indicators. This would result in a reduction of their administrative autonomy because they would have to subscribe to management contracts with foundations and nonprofitable organisations to handle funds and execute research and teaching activities.

13 Scholars at Risk, 2019. Free to Think report 2019. Access: https://www.scholarsatrisk.org/resources/free-to-think-2019/

${ }^{14}$ Kaiser, A.J., 2019. Brazil's Bolsonaro dismisses “imbecile" students as he faces biggest protests yet. The Guardian. 
Another feature of the bill includes the donation of the buildings and facilities of public universities to these funds, which would be managed privately to generate revenues. Although the government promises to send the bill to the National Congress February 2020, the programme has already rejected by the majority of the governing bodies of federal universities in late $2019 .{ }^{15}$

Probably because of this rejection, Bolsonaro's administration decided to alter the rules of how the rectors of the federal higher education institutions are selected in December 2019. This provisional legislation, which has immediate effect but also needs to be approved by the National Congress in one-hundred-and-twenty days otherwise it expires, facilitates the nomination of politically aligned governing boards of federal universities by the government. ${ }^{16}$

Brazilian public universities are still marked by big social gaps, as the majority of the people attending have higher incomes. Even if racial and class-based quotas succeeded in rebalancing inequalities in public universities, the rollback of affirmative action policies looms on the horizon as the recent cuts to funding for student halls, alimentation, transport and study scholarships, and other policies that allow lowincome students to go to university demonstrate. In this sense, market-oriented logics within the education system tend to reinforce inequalities and prevent access to universities for minority populations.

\section{Internationalisation}

In the Future-se program, the internationalisation of higher education program is focused on making universities responsible for their own funding, including securing money from private sector companies, following the same model of some of the IvyLeague universities, such as Harvard University. This would remove the responsibility of the state to fund universities and it would reinforce competition by highlighting the importance of international reputation and productivity. This

\footnotetext{
${ }^{15}$ Cafardo, R., Mengue, P., 2019. Maioria das universidades federais rejeita Future-se, do MEC Educação - Estadão. O Estado de São Paulo.

16 The rector is the principal director of Brazilian public universities. Rectors are usually appointed from a triple list prepared by a consultation of the academic community, which selects the winner. The president is under no obligation to that person appointed by the academic community, but it is traditional they do so. The provisional legislation intends to take away the power of universities to choose their own rectors.
} 
resembles models of internationalisation based on dominant practices from the Global North, especially North America.

Bolsonaro's government agenda for higher education has had an impact in at least three internationalisation programs: (1) the Programa Idiomas sem Fronteiras (Languages Without Borders, IsF), which supported students and academics to learn a second language; (2) the Programa Institucional de Internacionalização (CAPES/PrInt - Internationalisation Program), which supports the consolidation of strategic plans for the internationalization of third level institutions; and the (3) Programa de Doutorado Sanduiche no Exterior (CAPES/PDSE - University Exchange Doctoral Programme), which funds doctorate scholarships abroad.

Created to be an extension of the now redundant mobility programme, Programa Ciencia sem Fronteiras, the IsF gave more than 818,000 college students and teachers the opportunity to learn a second language. However, it was severely criticised by the Education Minister, Abraham Weintraub, who declared that the program was "inefficient". Created to support students and scholar in mobility programs abroad so they could learn a second language before leaving the country for their studies, the IsF was suspended in 2019 and no substitute was left in its place. In this sense, there is still no serious foreign language foundation in the Brazilian education system. The funding for CAPES-PrInt was frozen in May 2019 and 20\% the vacancies planned for 2019 were rescinded. This means that less visiting academics will be visiting Brazilian universities until 2023, when the program is expected to end. Similarly, the CAPES-PDSE had cancelled or temporarily suspended several scholarships and the scholarships that are available cannot be offered to new candidates. Whilst some funding was released again at a later date, only university courses with highest marks in the CAPES evaluation system had their funding reinstated. Given the complexity of the internationalisation of higher education in Brazil, the formulation of policies to support internationalisation must make it more equitable and accessible for every citizen. ${ }^{17}$

\footnotetext{
${ }_{17}$ Guimaraes, F.; Finardi, R; Casotti, C; 2019. Internationalization and Language Policies in Brazil: What is the Relationship? Revista Brasileira de Linguística Aplicada 19, 295-327.
} 


\section{The dismantling of Brazilian education and the "brain drain"}

In a scenario where investment in research and postgraduate education is not a priority, it is unsurprising that talented and promising academics decide to leave Brazil permanently to pursue their career in other countries. This only benefits developed countries that absorb high-qualified Brazilian talents such as postdoctoral researchers and professors. The research funding crisis deeply affects Brazilian scientists for years and this is not exclusive of Bolsonaro's government. For example, in 2018 during Temer's administration, the federal budget for science was cut by $44 \% .^{18}$

But last year was particularly difficult for Brazilian science. First, the suspension of funding for the universities' operational costs threatened researching facilities, such as laboratories and libraries. Second, the two main governmental agencies that fund science - CAPES and CNPq - suffered cuts in their budgets that seriously undermined their capacity to pay scholarships and research budgets (i.e. equipment, supplies and grants). Part of the Ministry of Science and Technology, which was subjected to a suspension of $42 \%$ of its budget in March 2019, ${ }^{19} \mathrm{CNPq}$ had a budget deficit of R\$300 million in 2019 that was only rectified in October 2019, when the National Congress and the Ministry of Finance authorised an extra budget for the agency so it could keep paying its eighty thousand or so scholarships. ${ }^{20}$ CAPES, linked to the Ministry of Education, faced similar difficulties to pay its ninety thousand or so scholarships for graduate students. During 2019, more than eight thousand scholarships were frozen. ${ }^{21}$

This situation contrasts with the past two decades during which science and graduate level education received increasing support. Between 2003 and 2014, the enrolment in Masters and $\mathrm{PhD}$ courses increased from 48,925 to 203,717, according to official

\footnotetext{
${ }^{18}$ Mega, E.R., 2019. Financial crisis looms at Brazilian science agency. Science 365, 731-731. https://doi.org/10.1126/science.365.6455.731

${ }^{19}$ Folha de Sao Paulo, 2019. Corte orçamentário de 42\% em ciência e tecnologia preocupa entidades - 03/04/2019 - Ciência - Folha. Folha de Sao Paulo.

20Moreno, A.C.M., 2019. Após 8 meses de avaliação, Ministério da Economia libera verba extra para o CNPq pagar bolsas de pesquisa. $\mathrm{G}$.

${ }^{21}$ Rodrigues, M., 2019. MEC anuncia desbloqueio de 3.182 bolsas de pós-graduação de cursos com alta avaliação. $\mathrm{G}$. 
numbers. In 2013, the budget for the Ministry of Science and Technology peaked at $\mathrm{R} \$ 9.5$ billion, double what it currently is. ${ }^{22}$ The previous policy of expanding academic and scientific resources clashed with the current austerity in these areas, which also led to the recent suspension of the recruitment of new teaching and research staff in public universities. The results have been severe. Today, people with Masters and $\mathrm{PhDs}$ suffer with the highest rates of unemployment in Brazil. ${ }^{23}$ Since 2016, prominent scientists have been leaving the country claiming that there is no funding to do leading research. ${ }^{24}$ The situation even more grave given that most of the scientific development in the country is carried out by graduate students, funded by government scholarships, which are now continuously under threat.

\section{Conclusion}

This article examined the threats to the higher education community in Brazil. The hostile environment created by the current administration is increasing political and financial pressures on scholars and students. The justification for the attacks on education is an alleged need to eliminate the "cultural Marxist" rhetoric and make universities more productive institutions. Aside from the futility of such a discourse, what is real about the anti-cultural Marxist rhetoric is that Bolsonaro's administration is against critical studies, especially if they are related to race, gender and feminism. These attacks, together with the decreasing investment in tertiary education, are a new facet of an educational policy agenda reframed through a neoliberal lens. It involves the incorporation of Brazilian universities into institutional models of evaluation that have been established by developed countries, where universities are measured through quality indicators that often ignore the reality of their context and local practices. ${ }^{25}$

\footnotetext{
${ }^{22}$ Alves, G., 2018. Recuperar orçamento da ciência é desafio para governo Bolsonaro- Ciência. Folha de Sao Paulo.

${ }^{23}$ Roscoe, B., Soares, I., 2019. Desemprego entre mestres e doutores no Brasil chega a 25\%. Correio Braziliense.

${ }^{24}$ Ciscati, R., 2016. Porque a cientista Suzana Herculano-Houzel decidiu dizer adeus ao Brasil. Época; Silveira, E., 2020. Fuga de cérebros: os doutores que preferiram deixar o Brasil para continuar pesquisas em outro país. BBC News Brasil. Available at: https://www.bbc.com/portuguese/brasil-51110626.

${ }^{25}$ Leite, D., Genro, M.E.H., 2012. Avaliação e internacionalização da educação superior: Quo vadis América Latina? Avaliação: Revista da Avaliação da Educação Superior (Campinas) 17, 763-785
} 
The assault unleashed against Brazilian universities is an expression of intolerance, which clashes directly with a need to maintain the free and independent academic environment. Aggressive far-right rhetoric against progressive ideas have been eroding conditions of security, academic freedom, institutional autonomy and causing high levels of stress and uncertainty for scholars and students. Even if erratic and contradictory, the current national policy for Brazilian public universities causes huge concerns. The cuts in funding prevent universities to function at minimum levels of quality, with serious impacts on research outputs and on the quality and international interest in Brazilian research. The consequences of the funding crisis is already being felt by scientific research community, with the suspension of scholarships and the limitation of attendance at international conferences. Bolsonaro's government seriously attacks Brazilian scientific research and higher education as public policies, which have taken decades to consolidate and were only starting to become inclusive.

\section{References}

Alves, G., 2018. Recuperar orçamento da ciência é desafio para governo BolsonaroCiência. Folha de Sao Paulo.

Cafardo, R., Mengue, P., 2019. Maioria das universidades federais rejeita Future-se, do MEC - Educação - Estadão. O Estado de Sáo Paulo.

Ciscati, R., 2016. Porque a cientista Suzana Herculano-Houzel decidiu dizer adeus ao Brasil. Época; Silveira, E., 2020. Fuga de cérebros: os doutores que preferiram deixar o Brasil para continuar pesquisas em outro país. BBC News Brasil. Available at: https://www.bbc.com/portuguese/brasil-51110626.

Época, 2019. Sete a cada dez universidades federais têm notas máximas em índice de qualidade do MEC. Época.

Folha de Sao Paulo, 2019. Corte orçamentário de 42\% em ciência e tecnologia preocupa entidades - 03/04/2019 - Ciência - Folha. Folha de Sao Paulo.

Guimaraes, F.; Finardi, R; Casotti, C; 2019. Internationalization and Language Policies in Brazil: What is the Relationship? Revista Brasileira de Linguística Aplicada 19, 295-327.

Kaiser, A.J., 2019. Brazil's Bolsonaro dismisses “imbecile” students as he faces biggest protests yet. The Guardian. 
Leite, D., Genro, M.E.H., 2012. Avaliação e internacionalizaçáo da educação superior: Quo vadis América Latina? Avaliação: Revista da Avaliação da Educação Superior (Campinas) 17, 763-785

Macedo, R.G.M., 2019. Políticas educacionais e a questáo do acesso ao ensino superior: notas sobre a deseducação. Cadernos de Campo (São Paulo 1991) 28, 2631; Costa, H.B. da, 2019. Estudantes do Prouni na crise do lulismo. Plural 26, 289311.

Mano, M. K.; Possas, M.; Azize, R. L.; Iamamoto, S. A. S. , 2019. Ataque do governo às universidades federais é tristemente ideológico. Blog do Sakamoto. https://blogdosakamoto.blogosfera.uol.com.br/2019/05/01/ataque-do-governo-asuniversidades-federais-e-tristemente-ideologico/ (accessed 1.18.20).

Mega, E.R., 2019. Financial crisis looms at Brazilian science agency. Science 365, 731-731. https://doi.org/10.1126/science.365.6455.731

Moreno, A.C.M., 2019. Após 8 meses de avaliação, Ministério da Economia libera verba extra para o CNPq pagar bolsas de pesquisa. G1.

Rodrigues, M., 2019. MEC anuncia desbloqueio de 3.182 bolsas de pós-graduação de cursos com alta avaliação. G1.

Roscoe, B., Soares, I., 2019. Desemprego entre mestres e doutores no Brasil chega a 25\%. Correio Braziliense.

Scholars at Risk, 2019. Free to Think report 2019. Access: https://www.scholarsatrisk.org/resources/free-to-think-2019/

Suzigan, W., Albuquerque, E. da M., 2011. The underestimated role of universities for the Brazilian system of innovation. Brazilian Journal of Political Economy 31, 330.

Times Higher Education, 2019. Best universities in Latin America 2019 [WWW Document]. Times Higher Education (THE). URL https://www.timeshighereducation.com/student/best-universities/best-universitieslatin-america (accessed 2.7.20).

Tosi, M., 2019. Pesquisadores cearenses participam de equipe internacional para cirurgia com pele de tilápia. O Povo.

Valente, R.R., Berry, B.J.L., 2017. Performance of Students Admitted through Affirmative Action in Brazil. Latin American Research Review 52, 18-34. 
Vieira, R.S., Arends-Kuenning, M., 2019. Affirmative action in Brazilian universities: Effects on the enrollment of targeted groups. Economics of Education Review 73, 101931.

Vieira, V., 2015. Governo corta 47\% dos investimentos previstos para as federais Educação - Estadão. O Estado de São Paulo. 